\title{
Bribe Payments and Innovation in Developing Countries: Are Innovating Firms Disproportionately Affected?
}

\author{
Meghana Ayyagari, Asli Demirgüç-Kunt, and Vojislav Maksimovic*
}

\begin{abstract}
Innovating firms pay more bribes than noninnovators across 25,000 firms in 57 countries. The difference is larger in countries with more bureaucratic regulation and weaker governance. Innovators that pay bribes do not receive better services and do not have greater propensity to engage in other illegal activities such as tax evasion. Thus, innovators are more likely to be victims of corruption than perpetrators. Our findings point to the challenges facing entrepreneurs in developing countries and are consistent with the view that rent seeking by government officials unlike private criminal activity is more likely to target innovators.
\end{abstract}

\section{Introduction}

The adverse effects of corruption on growth and development across countries are the subject of much attention in economics and finance ${ }^{1}$ and among policy makers. It is also widely recognized that innovation and entrepreneurship are the engines of economic growth and that understanding the determinants of innovation is a crucial first step in understanding the differences in technological

*Ayyagari, ayyagari@gwu.edu, School of Business, George Washington University, 2201 G St NW, Washington, DC 20052; Demirgüç-Kunt, ademirguckunt@worldbank.org, Development Research Group, World Bank, 1818 H St NW, Washington, DC 20433; Maksimovic, vmax@ rhsmith .umd.edu, Smith School of Business, University of Maryland, 4417 Van Munching Hall, College Park, MD 20742. This research was supported by a grant from the National Science Foundation (NSF). We thank Julian Atanassov (the referee), Michael Bradley, Mihir Desai, Robert Goldstein, Ross Levine, Paul Malatesta (the editor), Ron Masulis, Amit Seru, Hans Stoll, S. Vishwanathan, and seminar participants at the 2009 National Bureau of Economic Research (NBER) Entrepreneurship Working Group, 2009 Conference on the Role of Government Regulation in Corporate Finance at Vanderbilt University, and the 2008 Annual Meetings of the Academy of International Business for their comments and suggestions. This paper's findings, interpretations, and conclusions are entirely those of the authors and do not necessarily represent the views of the World Bank, its Executive Directors, or the countries they represent.

${ }^{1}$ See Shleifer and Vishny (1993), Mauro (1995), and Ades and Di Tella (1997). Svensson (2003), (2005) provides detailed reviews on this subject. 
progress and income levels across countries. ${ }^{2}$ However, there has been very little research exploring the link between these two key determinants of growth.

Murphy, Shleifer, and Vishny (1993) argue that innovators are more vulnerable to public corruption than established firms for several reasons: First, innovations that involve activities such as changing the physical layout of a factory, installing telephones, acquiring equipment, opening new premises, importing a new category of goods, or registering a new trademark increase interactions with government employees who have the power to extort the firm, and thus increase the likelihood that innovating firms pay more bribes than noninnovators. For instance, consider the case of the Greek entrepreneur profiled in the media ${ }^{3}$ who wanted to spearhead innovation in e-business in the country by selling olive products online. To his surprise, he had to go through several layers of approval from multiple government agencies that included subjecting his board members to medical exams, since the e-business was classified as a food company. The president of the National Confederation of Hellenic Commerce, a trade association in Athens, attributed the stringency of the approval process to the entrepreneur's unwillingness to pay the "speed tax" or bribes to circumvent various regulations.

Second, all those innovating firms that are not part of entrenched lobbies or politically connected do not have the same level of control rights in the bargaining process with the government as established incumbents. ${ }^{4}$ Third, the very nature of innovation involves uncertainty and, as discussed by Murphy et al. (1993), innovative projects are typically long term, which offers more opportunities for rent seeking by corrupt government officials.

However, we know little from existing empirical finance literature about whether innovators pay more bribes because it enables them to avoid bureaucratic regulation or whether innovators are particularly targeted by corrupt officials.

In this paper, we study the bribery of government officials in developing countries and how this is associated with firm innovation. ${ }^{5}$ Specifically, we

\footnotetext{
${ }^{2}$ See, for example, Schumpeter (1934), (1942), Baumol (2002), Aghion and Durlauf (2005), and Michalopoulos, Laeven, and Levine (2009) on the importance of innovation for growth. Hall and Jones (1999) show that differences in income levels across countries can be explained by differences in their technological progress.

3 "A Tale of Greek Enterprise and Olive Oil, Smothered in Red Tape," The New York Times, March 18, 2012.

${ }^{4}$ For instance, De Soto (1989) documents in detail the bribes, delays, and regulatory headaches that business entrepreneurs without political influence in Peru face when trying to open a new business. Take the case of India, where the elaborate system of licenses, regulations, and red tape, called the "license raj" prior to liberalization in 1990, affected innovation and entrepreneurship, and the only businesses that managed to succeed were established business houses (e.g., Hazari (1966), Aghion, Burgess, Redding, and Zilibotti (2005)). Several other cross-country studies, including Djankov, La Porta, Lopez-de-Silanes, and Shleifer (2002) and Klapper, Laeven, and Rajan (2006), document the regulatory hurdles faced by entrepreneurs.

${ }^{5}$ We focus on corruption that is costly to the firm rather than being a benefit to the firm and a cost to society. While both kinds of corruption exist, the literature has generally reached a consensus that corruption is a cost to entrepreneurs rather than "grease." Several papers using surveys report corruption as being an important obstacle to doing business (Beck, Demirgüç-Kunt, and Maksimovic (2005), Fisman and Svensson (2007), Johnson, Kaufmann, and Zoido-Lobaton (1998), and Hellman, Jones, and Kaufmann (2003)). On a cross-country level, other studies show that corruption hinders growth and investment (Mauro (1995), De Soto (1989), Frye and Shleifer (1997), Berkowitz and Li (2000), Svensson (2003), and Ahlin and Pang (2008)).
} 
examine whether innovating firms pay more bribes than noninnovators. Are there particular innovative activities, such as introducing new products and introducing new technology, associated with greater bribe payments to government officials? We also examine if innovating firms that bribe receive special advantages in dealing with bureaucracy and regulation. Finally, we investigate if innovating firms engage in other illegal activities such as tax evasion or paying private protection money. To answer these questions, we use a rich multicountry data set, the World Bank Enterprise Surveys (ES), ${ }^{6}$ sampling over 25,000 firms (80\% of which are small and medium-sized enterprises) in 57 countries. The surveys provide information on firms' innovation projects, bribe payments, and tax evasion in addition to firm demographics.

Univariate statistics show that there is a wide variation in the distribution of firms paying and not paying bribes across countries and across firm characteristics. In particular, summary statistics show that firms in more regulated economies pay more bribes, and innovating firms pay more bribes than noninnovators.

When we examine firm characteristics associated with bribe payments in a multivariate setting, we find that smaller ${ }^{7}$ and younger firms report paying a larger percentage of their sales as bribe payments. Individual- or family-owned firms pay higher bribes than firms owned by another corporation, bank, investment fund, manager/employees, or the state. Controlling for country and industry fixed effects and several firm characteristics, we find that the odds of having to pay bribes are 1.36 times higher for innovating firms than for noninnovators. Thus, in our sample of countries, corruption acts as a tax on innovation.

We also find that innovators pay a higher percentage of their sales as bribes in less-developed countries, in countries with more bureaucratic regulation in starting and operating a business, and in countries with weak governance as measured by government effectiveness, rule of law, control of corruption, and regulatory quality.

Our results are robust to using alternate measures of dependent variables and to controlling for potential omitted variable bias, where we control for a number of alternate factors including firm profitability, size of the city in which the firm is located (big cities may have more bureaucratic governments and red tape), and size of the firm's customers. For a smaller sample of countries with panel data, we use firm fixed effects and find a positive association between differences in innovation rates and differences in bribe payments, suggesting that our results are not driven by unobserved firm heterogeneity.

We do not find that innovating firms that pay bribes receive greater benefits in obtaining government services than firms that do not pay bribes. By contrast,

\footnotetext{
${ }^{6}$ See Graham and Harvey (2001) and Graham, Harvey, and Rajgopal (2005) for the merits of survey data in corporate finance compared to archival data sources. The World Business Environment Survey (WBES), which was a precursor to the World Bank ES, has been used by recent studies looking at corruption in bank lending (e.g., Barth, Lin, Lin, and Song (2009), Houston, Lin, and Ma (2011)).

${ }^{7}$ While small firms face significant constraints in developing economies (e.g., Beck, DemirgüçKunt, and Maksimovic (2005), Ayyagari, Demirgüç-Kunt, and Maksimovic (2013)), they also contribute significantly to total employment and job creation in these economies (see Ayyagari, Demirgüç-Kunt, and Maksimovic (2014)).
} 
we find that innovators with government contracts pay a greater percentage of the contract value as bribes than do noninnovators. Our results are consistent with Kaufmann, Montoriol-Garriga, and Recanatini (2008), who analyze survey data from officials of different government agencies in Peru and find that corruption reduces the supply of basic public services. They find that bribery acts as a regressive tax, since low-income households are discriminated against in seeking government services, and some households are discouraged enough by this tax to not seek the service. Our results on the victimization of innovators offer suggestive evidence that corruption discourages innovation by increasing the costs borne by innovators due to the bribery tax.

We do not find that innovating firms are more likely to evade taxes than noninnovators. While some theories suggest that government corruption breaks an implicit contract between citizens and the state, causing firms to retaliate by evading taxes, we find no evidence that innovating firms that pay bribes evade more taxes than noninnovating firms that pay bribes We also find no association between innovation and private protection payments to organized crime to prevent violence. This is consistent with Murphy et al. (1993), who differentiate between private and public rent seeking and argue that private rent seeking attacks the wealthy rather than the innovative sector of the economy, whereas public rent seeking particularly targets innovators.

Our paper contributes to our understanding of firm-level corruption in developing countries. Most cross-country corruption studies treat countries as monoliths, without attention to corruption in particular firms or industries. By contrast, we focus on firms and industries, and in particular, innovative firms. Thus, the analysis in this paper has significant implications for anticorruption policy reforms by emphasizing the importance of looking at which types of firms are most affected. ${ }^{8}$

The remainder of the paper is as follows: Section II describes the data and empirical methodology. Section III presents firm-level summary statistics on bribes. In Section IV, we show that innovators pay more bribes than noninnovators. In Section V, we investigate if innovators are recipients of special concessions and if they participate in other illegal activities. Section VI concludes.

\section{Data and Empirical Methodology}

\section{A. Data}

We use the World Bank ES, which use standardized survey instruments to benchmark the investment climate of individual economies across the world and to analyze firm behavior and performance. The surveys sample from the universe of registered businesses in each country using standardized survey instruments

\footnotetext{
${ }^{8}$ Corruption has been at the forefront of policy reform. Over the period 1990 to 2006, the World Bank Group approved more than $\$ 20$ billion in public sector reform programs, a key component of which were anticorruption and governance programs. However, as highlighted by a recent World Bank report and profiled in a Washington Post editorial ("Corruption Reality Check," May 2008), much of this reform money achieved no results, and what little progress that took place was in countries where it was needed the least.
} 
and follow a stratified random sampling methodology. ${ }^{9}$ All the surveys in our sample were administered during 2002-2005.

The ES have two unique advantages that make them suitable for investigating the relation between innovation and corruption. First, the surveys have detailed information on the extent of innovation that the firms undertake. The ES allow for a broader definition of innovation, to include not only core innovative activities, such as the introduction of new products and new technologies, but also other types of activities that promote knowledge transfers, such as signing joint ventures with foreign partners or obtaining new licensing agreements, and other actions that adapt the organization of the firm's business activities, such as opening a new plant or outsourcing a productive activity. See Schumpeter (1942), Segerstrom (1991), Grossman and Helpman (1991), Acemoglu, Aghion, and Zilibotti (2006), and Ayyagari, Demirgüç-Kunt, and Maksimovic (2011) for highlighting the importance of thinking about innovation broadly in developing countries. To capture firm innovation, we use a dummy variable, Innovator, which takes the value of 1 if the firm developed a new product line, and 0 otherwise.

The second unique aspect of our data is that the surveys contain information on bribe payments by firms to public officials, which help us understand the extent to which firms are victimized. In addition, we have information on the firm's participation in other illegal activities such as tax avoidance, which helps us explore the role of firms as perpetrators. One of the concerns with self-reported measures on corruption is whether reliable data can be collected on illegal activity. However, Fisman and Svensson (2007) note that with appropriate data collection techniques, surveys have been able to elicit detailed information from firm managers on corruption. With the ES, given the sensitive nature of the data, government officials are not directly involved in data collection, ${ }^{10}$ nor are they given any raw data or any information that allows them to identify the responses of individual firms. Thus, firm names and their identities are confidential information. Furthermore, the surveys are conducted by the World Bank in partnership with the local private sector, such as independent chambers of commerce or business associations in which the local firms have confidence. See Web Appendix A (www.jfqa.org) for more details on how the ES are an important first step in understanding firms' illegal activities.

As a measure of bribe payments, we construct the variable, Bribes, which is firm responses to the question, "What percent of annual sales value does a typical firm like yours spend on gifts or informal payments to public officials to 'get things done' with regard to customs, taxes, licenses, regulations, services, etc.?”

We do, however, recognize that these data are not census data and subject to the usual caveats and biases in survey data such as nonresponse and measurement

\footnotetext{
${ }^{9}$ The ES and their precursor, the WBES, have been used to investigate a series of questions in finance and development economics, including the relation between property rights and contracting institutions (e.g., Acemoglu and Johnson (2005), Ayyagari, Demirgüç-Kunt, and Maksimovic (2008b)), investment climate and business environment obstacles to growth (e.g., Beck et al. (2005), Ayyagari, Demirgüç-Kunt, and Maksimovic (2008a)), firm-financing patterns (e.g., Beck et al. (2008), Cull and $\mathrm{Xu}$ (2005), and Ayyagari, Demirgüç-Kunt, and Maksimovic (2010)), and dispute resolution via courts (e.g., Djankov, La Porta, Lopez-de-Silanes, and Shleifer (2003)).

${ }^{10}$ The World Bank does coordinate with the national statistics agencies where possible to obtain the sample frame and other information.
} 
error. For instance, it could be that innovating firms exaggerate the extent to which they are shaken down by government officials more than noninnovators. Alternatively, innovators may underreport information on bribes and tax compliance, believing (perhaps irrationally) that they have more to lose than noninnovators by reporting accurately.

\section{B. Empirical Methodology}

To test whether firm innovation is associated with the amount of bribes firms pay to public officials, for firm $i$ in industry $j$ in country $k$, we run the following regression:

$$
\begin{aligned}
\text { Bribes }_{i, j, k}= & \alpha+\beta_{1} \text { Innovator }_{i, j, k}+\beta_{2} \text { Firm Size dummies }_{i, j, k} \\
+ & \beta_{3} \text { Age }_{i, j, k}+\beta_{4} \text { Legal Status dummies }_{i, j, k} \\
+ & \beta_{5} \text { Family Owned dummy }_{i, j, k}+\beta_{6} \text { Capacity } \\
& \text { Utilization }_{i, j, k}+\beta_{7} \text { Foreign Ownership dummy }_{i, j, k} \\
+ & \beta_{8} \text { Exporter dummy }_{i, j, k}+\beta_{9} \boldsymbol{I}_{j}+\beta_{10} \boldsymbol{C}_{k} \\
+ & \beta_{11} \text { Year dummies }_{i, j, k}, \quad k=1, \ldots, 57, \\
& j=1, \ldots, 5,
\end{aligned}
$$

where $\boldsymbol{I}_{j}$ and $\boldsymbol{C}_{k}$ are industry and country fixed effects, respectively.

As seen in equation (1), we control for a number of variables that might influence the relation between innovation and bribes. As a measure of firm performance, we use the firm's average Capacity Utilization, which is defined as the amount of output actually produced relative to the maximum amount that could be produced with the firm's existing machinery and equipment and regular shifts. As alternate indicators of firm performance, we use Sales Growth over the past year and Labor Productivity, which is the ratio of labor productivity of the firm to the mean labor productivity in its country, where labor productivity is defined as (Total Sales - Raw Material Costs)/(Total Number of Workers in the previous year). Scaling by the country mean allows us to account for the wide heterogeneity in firm performance. Using a ratio also allows us to avoid dealing with exchange rate fluctuations in the time period. We prefer capacity utilization as the main performance measure, since labor productivity is a direct function of firm sales and hence may also be misreported, and we prefer capacity utilization to sales growth, since the latter is available for a much smaller sample.

The ES also contain detailed information on firm size, age, legal status, industry sector, and ownership, all of which are used as controls in our study. The survey defines firm size on the basis of the number of full-time workers: ${ }^{11}$ Small firms have 1-19 employees, medium-sized firms employ 20-99 employees, and large firms employ 100 or more employees.

Our data consist of pooled cross sections over time, since some of the countries are surveyed in multiple years, but during each year a new random sample

\footnotetext{
${ }^{11}$ Employment is typically the most reliable figure in developing countries. Hence, the number of full-time workers is used as a measure of firm size by the World Bank Group and other international survey teams, including the Regional Program on Enterprise Development (RPED) and the Oxford University Centre for the Study of African Economies.
} 
is taken from the population. As suggested by Wooldridge ((2002), p. 129), we use the pooled ordinary least squares (OLS) estimator with country, industry, and year fixed effects. ${ }^{12}$ However, as discussed later, our results are robust to different estimation techniques.

For a smaller sample of 27 transition countries, the ES were implemented in 2002 and 2005 (the Business Environment and Enterprise Performance Surveys (BEEPS)) as a joint initiative of the European Bank for Reconstruction and Development (EBRD) and the World Bank. The BEEPS have more detailed data on profit margins and alternate measures of corruption, which we use as robustness checks. In addition, the BEEPS data contain a panel component, where 1,436 firms that were surveyed in 2002 were surveyed again in 2005 . We use the panel data and control for firm fixed effects to verify that our results are not being driven by unobserved firm heterogeneity.

\section{Summary Statistics}

Panel A of Table 1 reports the summary statistics for the variables and indicates that the mean bribe payments in the sample are only $1.34 \%$. A large number of firms in our sample (37\%) are innovators who introduced or developed a new product line. The mean capacity utilization is $78.8 \%$. The sample is largely dominated by small and medium-sized firms: Small firms make up $44 \%$ of the sample, medium-sized firms constitute $32 \%$, and large firms constitute $24 \%$ of the overall sample. In terms of legal status, $39 \%$ of the sample is composed of corporations, $32 \%$ are sole proprietorships, $21 \%$ are partnerships, $2 \%$ are cooperatives, and $6 \%$ are other legal structures. The average firm age in the sample is 15.62 years. Panel A also shows that $13 \%$ of the sample of firms is composed of foreign firms, and $21 \%$ of the firms are exporters.

Panel B of Table 1 reports summary statistics depending on the level of bureaucratic regulation, as measured by entry regulation in the economy (De Soto (1989), Djankov et al. (2002)). Specifically, we use the number of procedures required to start a business, averaged over 2004-2005 from the World Bank Doing Business Indicators, which in our sample of countries ranges from 4 (Ireland) to 18 (Uganda), with a median value of 10.7 . We classify countries into high and low regulation, depending on whether the number of procedures required for starting a business in that country lies at or above the median (high) or below the median (low) values, respectively. We find that the level of bribe payments is higher in the high-regulation countries.

In Panel $\mathrm{C}$ of Table 1, we present statistics on average bribe payments across different types of firms. Small firms report the highest bribe payments $(1.50 \%)$ compared to medium-sized $(1.46 \%)$ and large firms $(1.03 \%)$. In the raw data, we find a large variation in the percentage of sales revenue paid out as bribes by innovating firms. While the mean bribe payment among innovating firms is

\footnotetext{
${ }^{12}$ We find no material difference in our results if we use an expanded set of fixed effects including Country $\times$ Industry, Industry $\times$ Firm Size, Country $\times$ Firm Size, and Country $\times$ Industry $\times$ Firm Size dummies. We do not report these specifications in the paper because the main effects on Size and Industry are hard to interpret in the presence of so many interactions.
} 
$1.62 \%$ and significantly higher than that paid by noninnovators $(1.23 \%)$, we find that $12.8 \%$ of innovators pay more than $5 \%$ of their revenue in bribes, while the corresponding figure for noninnovators is $9.7 \%$. In unreported statistics, we also find that the average level of bribes is higher for firms that are unincorporated, domestic, nonexporters, and in the agro-industry.

\section{TABLE 1}

\section{Summary Statistics}

The variables are described as follows: Bribes is the percentage of annual sales value that a typical firm spends on gifts or informal payments to public officials to "get things done" with regard to customs, taxes, licenses, regulations, services, etc. Innovator is a dummy variable that takes the value of 1 if the firm developed a new product line, and 0 otherwise. Capacity Utilization is defined as the amount of output actually produced relative to the maximum amount that could be produced with the firm's existing machinery and equipment and regular shifts. Firm Size dummies take values 1 to 3 for Small firms (1-19 employees), Medium firms (20-99 employees), and Large firms ( $\geq 100$ employees), respectively. Corporation, Partnership, Cooperative, Sole Proprietorship, and Other Legal Status are all dummy variables that take the value of 1 if the firm is of the corresponding legal form, and 0 otherwise. Age is the year of the survey - year the firm was established. Sector dummies are 5 industry sector dummy variables for Agro-Industry, Manufacturing, Construction, Services, and Other. Foreign Ownership is a dummy variable that takes the value of 1 if the firm is foreign owned, and 0 otherwise. Exporter is a dummy variable that takes the value of 1 if the firm is an exporter, and 0 if it is a nonexporter. Leve of Bureaucratic Regulation is the number of procedures required to start a business averaged over 2004-2005 from the World Bank Doing Business Indicators. All variables and their sources are described in Web Appendix D.

Panel A. Summary Statistics

\begin{tabular}{|c|c|c|c|c|c|}
\hline Variable & $N$ & Mean & Std. Dev. & Minimum & Maximum \\
\hline Bribes & 25,761 & 1.34 & 4.53 & 0 & 100 \\
\hline Innovator & 25,761 & 0.37 & 0.48 & 0 & 1 \\
\hline Capacity Utilization & 25,761 & 78.80 & 20.40 & 1 & 106 \\
\hline Firm Size dummies & 25,761 & 1.71 & 0.78 & 1 & 3 \\
\hline Corporation & 25,761 & 0.39 & 0.49 & 0 & 1 \\
\hline Partnership & 25,761 & 0.21 & 0.41 & 0 & 1 \\
\hline Cooperative & 25,761 & 0.02 & 0.14 & 0 & 1 \\
\hline Sole Proprietorship & 25,761 & 0.32 & 0.47 & 0 & 1 \\
\hline Other Legal Status & 25,761 & 0.06 & 0.24 & 0 & 1 \\
\hline Age & 25,761 & 15.62 & 15.96 & 0 & 202 \\
\hline Sector dummies & 25,761 & 1.66 & 0.89 & 1 & 5 \\
\hline Foreign Ownership & 25,761 & 0.13 & 0.34 & 0 & 1 \\
\hline Exporter & 25,761 & 0.21 & 0.41 & 0 & 1 \\
\hline
\end{tabular}

Panel B. Bribes by Countries' Level of Bureaucratic Regulation

\begin{tabular}{lcc} 
& No. of Countries & Bribes \\
\cline { 2 - 2 } & 31 & 1.14 \\
Low Regulation & 34 & 2.22 \\
High Regulation & 65 & \\
Total & &
\end{tabular}

Panel C. Bribes by Firm Characteristics

\begin{tabular}{lrr} 
& No. of Firms & Bribes \\
\cline { 2 - 2 } Firm Size & & \\
Small (1-19) & 13,559 & 1.50 \\
Medium (20-99) & 9,107 & 1.46 \\
Large ( $\geq 100)$ & 6,870 & 1.03 \\
Total & 29,536 & \\
Innovators versus Noninnovators & & \\
Innovators & 9,888 & 1.62 \\
Noninnovators & 16,906 & 1.23 \\
Total & 26,794 & \\
\hline
\end{tabular}

\section{Are Bribe Payments a Tax on Innovation?}

In this section, we investigate whether innovating firms are particularly affected by bribe payments, since they are more subject to being victimized by government officials due to their greater need for public goods compared to other 
firms. If bribe payments are a tax on innovation, we should expect to see that innovating firms have to give a higher percentage of their sales as gifts or informal payments to public officials (after controlling for general firm characteristics). Table 2 shows the relation between innovation and bribe payments using different

TABLE 2

\section{Corruption as a Tax on Innovation}

The regression model in columns $1-8$ is Bribes $=\alpha+\beta_{1}$ Innovator $+\beta_{2}$ Capacity Utilization $+\beta_{3}$ Sales Growth $+\beta_{4}$ Labor Productivity $+\beta_{5}$ Firm Size dummies $+\beta_{6}$ Family Owned dummy $+\beta_{7}$ Legal Status dummies $+\beta_{8}$ Age $+\beta_{9}$ Foreign Ownership dummy $+\beta_{10}$ Exporter dummy $+\beta_{11}$ Industry Sector dummies $+\beta_{12}$ Year dummies $+\beta_{13}$ Country dummies $+\epsilon$. Bribes is the percentage of annual sales value that a typical firm spends on gifts or informal payments to public officials to "get things done" with regard to customs, taxes, licenses, regulations, services, etc. Protection Payments is the percentage of total sales used to buy protection (e.g., payments to organized crime to prevent violence). Innovator is a dummy variable which takes the value of 1 if the firm developed a new product line, and 0 otherwise. Capacity Utilization is defined as the amount of output actually produced relative to the maximum amount that could be produced with the firm's existing machinery and equipment and regular shifts. Labor Productivity is the ratio of labor productivity of the firm to the mean labor productivity in its country, where labor productivity is defined as (Total Sales - Raw Material Costs)/(Total Number of Workers in the previous year). Sales Growth is defined as the percentage increase in sales over the past year. Firm Size dummies take values 1 to 3 for Small firms ( $1-19$ employees), Medium firms (20-99 employees), and Large firms ( $\geq 100$ employees), respectively. Age is the year of the survey - year the firm was established. Family Owned dummy takes the value of 1 if the largest shareholder is an individual or family. Legal Status dummies consist of dummy variables for the following legal forms: Corporation, Partnership, Cooperative, Sole Proprietorship (omitted category), and Other Legal Status. Foreign Ownership is a dummy variable that takes the value of 1 if the firm is foreign owned, and 0 otherwise. Exporter is a dummy variable that takes the value of 1 if the firm is an exporter, and 0 if it is a nonexporter. Industry Sector dummies are 5 industry sector dummy variables for Agro-Industry, Manufacturing, Construction, Services, and Other. The regressions in columns 1-8 are estimated using OLS with standard errors clustered at the country level. All variables and their sources are described in Web Appendix D. ${ }^{a},{ }^{b}$, and ${ }^{\mathrm{C}}$ indicate significance at the $1 \%, 5 \%$, and $10 \%$ levels, respectively.

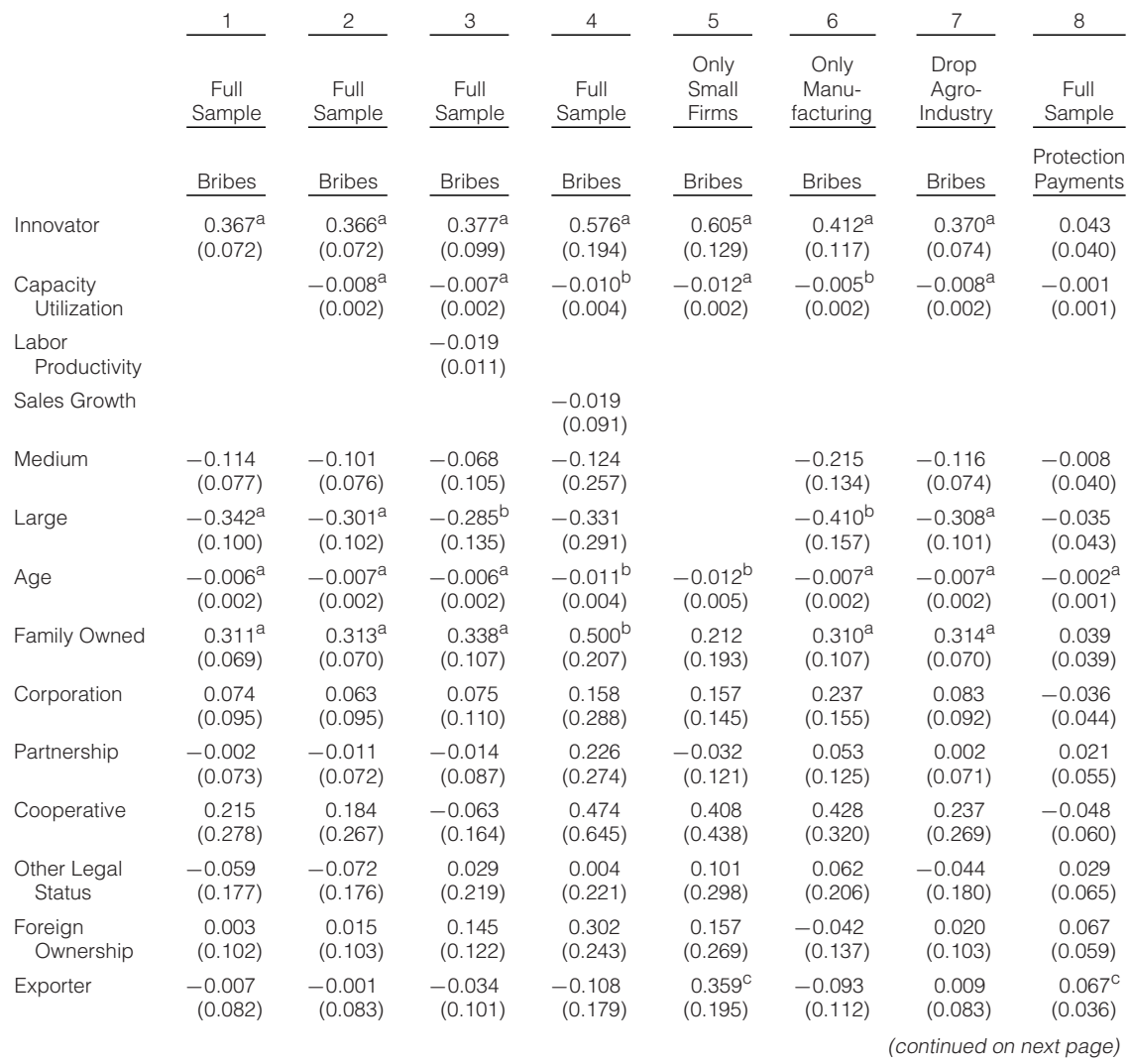




\begin{tabular}{|c|c|c|c|c|c|c|c|c|}
\hline \multicolumn{9}{|c|}{$\begin{array}{l}\text { TABLE } 2 \text { (continued) } \\
\text { Iption as a Tax on Innovation }\end{array}$} \\
\hline & 1 & 2 & 3 & 4 & 5 & 6 & 7 & 8 \\
\hline & $\begin{array}{c}\text { Full } \\
\text { Sample } \\
\end{array}$ & $\begin{array}{c}\text { Full } \\
\text { Sample } \\
\end{array}$ & $\begin{array}{c}\text { Full } \\
\text { Sample } \\
\end{array}$ & $\begin{array}{c}\text { Full } \\
\text { Sample } \\
\end{array}$ & $\begin{array}{l}\text { Only } \\
\text { Small } \\
\text { Firms }\end{array}$ & $\begin{array}{c}\text { Only } \\
\text { Manu- } \\
\text { facturing } \\
\end{array}$ & $\begin{array}{r}\text { Drop } \\
\text { Agro- } \\
\text { Industry } \\
\end{array}$ & $\begin{array}{c}\text { Full } \\
\text { Sample } \\
\end{array}$ \\
\hline & Bribes & Bribes & Bribes & Bribes & Bribes & Bribes & Bribes & $\begin{array}{l}\text { Protection } \\
\text { Payments } \\
\end{array}$ \\
\hline Services & $\begin{array}{c}0.059 \\
(0.062)\end{array}$ & $\begin{array}{c}0.095 \\
(0.063)\end{array}$ & $\begin{array}{c}0.104 \\
(0.091)\end{array}$ & $\begin{array}{c}0.568 \\
(0.613)\end{array}$ & $\begin{array}{c}0.152^{C} \\
(0.087)\end{array}$ & & $\begin{array}{c}0.095 \\
(0.063)\end{array}$ & $\begin{array}{c}0.083^{C} \\
(0.045)\end{array}$ \\
\hline Agro-Industry & $\begin{array}{r}-0.005 \\
(0.283)\end{array}$ & $\begin{array}{c}0.010 \\
(0.263)\end{array}$ & $\begin{array}{c}0.339 \\
(0.418)\end{array}$ & $\begin{array}{c}0.527 \\
(0.509)\end{array}$ & $\begin{array}{c}0.477 \\
(0.585)\end{array}$ & & & $\begin{array}{r}-0.168 \\
(0.187)\end{array}$ \\
\hline Construction & $\begin{array}{c}0.693^{a} \\
(0.096)\end{array}$ & $\begin{array}{c}0.716^{a} \\
(0.096)\end{array}$ & $\begin{array}{c}0.600^{a} \\
(0.130)\end{array}$ & $\begin{array}{c}0.405 \\
(0.858)\end{array}$ & $\begin{array}{c}0.735^{a} \\
(0.141)\end{array}$ & & $\begin{array}{c}0.719^{a} \\
(0.097)\end{array}$ & $\begin{array}{c}0.054 \\
(0.045)\end{array}$ \\
\hline Other Sector & $\begin{array}{c}0.350 \\
(0.258)\end{array}$ & $\begin{array}{c}0.352 \\
(0.255)\end{array}$ & $\begin{array}{c}0.603 \\
(0.378)\end{array}$ & $\begin{array}{r}-0.629 \\
(0.521)\end{array}$ & $\begin{array}{r}-0.286 \\
(0.533)\end{array}$ & & $\begin{array}{c}0.327 \\
(0.264)\end{array}$ & $\begin{array}{c}0.040 \\
(0.085)\end{array}$ \\
\hline Constant & $\begin{array}{c}2.482^{a} \\
(0.132)\end{array}$ & $\begin{array}{c}3.107^{a} \\
(0.166)\end{array}$ & $\begin{array}{c}1.509^{a} \\
(0.280)\end{array}$ & $\begin{array}{c}1.596^{a} \\
(0.476)\end{array}$ & $\begin{array}{c}3.202^{a} \\
(0.263)\end{array}$ & $\begin{array}{c}2.343^{a} \\
(0.220)\end{array}$ & $\begin{array}{c}3.064^{a} \\
(0.168)\end{array}$ & $\begin{array}{c}1.980^{a} \\
(0.230)\end{array}$ \\
\hline $\begin{array}{l}\text { No. of firms } \\
\text { No. of countries } \\
\text { Adj. } R^{2}\end{array}$ & $\begin{array}{c}25,761 \\
57 \\
0.055\end{array}$ & $\begin{array}{c}25,761 \\
57 \\
0.056\end{array}$ & $\begin{array}{c}16,978 \\
53 \\
0.047\end{array}$ & $\begin{array}{c}7,470 \\
31 \\
0.033\end{array}$ & $\begin{array}{l}12,745 \\
57 \\
0.062\end{array}$ & $\begin{array}{c}13,594 \\
57 \\
0.041\end{array}$ & $\begin{array}{c}25,482 \\
57 \\
0.057\end{array}$ & $\begin{array}{c}17,417 \\
50 \\
0.128\end{array}$ \\
\hline
\end{tabular}

controls for firm performance and across different samples. In all specifications, we drop firms reporting greater than $50 \%$ state ownership.

Columns 1 and 2 of Table 2 present results for the full sample of firms with and without controls for capacity utilization. In both instances, we find that innovating firms on average pay $0.37 \%$ more of their sales as bribes to public officials than noninnovators. Column 2 shows a negative association between capacity utilization and bribe payments. This implies that bribes are a lower proportion of their overall costs for firms operating efficiently and suggests that bribes are determined relative to the firm's capacity.

The positive association between innovation and bribe payments holds when we include additional controls for firm performance using different proxies (labor productivity ratio and sales growth) as in columns 3 and 4 . The results in the specification with sales growth are stronger (innovating firms pay $0.58 \%$ more of their sales as bribes), but the number of observations is down to 7,470 firms in 31 countries. In unreported results, we find similar results when we replace past year sales growth with sales growth over the past 2 years or sales growth lagged by 1 year. In unreported specifications where we control for profit reinvestment rates, we again find that innovation is positively associated with bribe payments, whereas there is no significant association between profit reinvestment rates and bribes. Thus, we find that while firm performance by itself is negatively associated with bribe payments, innovating firms in particular report having to pay higher bribes. In subsequent specifications, we rely on capacity utilization as our main performance measure.

Smaller and younger firms report paying a larger percentage of their sales as bribe payments. Individual- or family-owned firms pay higher bribes than if the firm was owned by another corporation, bank, investment fund, manager/ employees of the firm, or the state. Across industry sectors, we find that firms in the construction industry pay higher bribes than firms in the manufacturing 
industry. We find no variation in bribe payments across legal organization of the firm, domestic versus foreign ownership, and whether the firm is an exporter or not.

In column 5 of Table 2 we repeat the specification in column 2 for a sample of only small firms. We find that small innovating firms pay a larger fraction of their sales as bribe payments than small noninnovators, suggesting that small innovating firms may be particularly victimized. Column 6 restricts the sample to manufacturing firms only, and again we find a strong association between innovation and bribe payments. In column 7 , we drop agro-industry firms, since in unreported summary statistics agro-industry firms have the highest bribe payments. We continue to find a strong association between innovation and bribe payments.

The link between innovation and bribe payments is also economically significant. From columns 1 and 2 of Table 2, we find that innovating firms on average pay $0.37 \%$ more of their sales as bribes to public officials than do noninnovators. This is quite large, given that the average bribe payment in the full sample of firms is $1.43 \%$ of the sales revenue. In addition, we find that certain types of innovators pay a larger portion of their sales as bribe payments. For instance, column 5 shows that small innovating firms pay $0.61 \%$ more of their sales as bribes to public officials than do small noninnovators. There is also variation across different industries. Innovating firms in the manufacturing sector (col. 6) and construction pay over $0.4 \%$ of their sales revenue as bribes compared to noninnovating firms in those industries. ${ }^{13}$

In column 8 of Table 2, as a placebo test, we investigate if innovators are subject to bribe payments to private parties other than the government. If innovating firms are victims of corruption by public officials rather than firms that pay bribes to bend rules and get ahead in their business, we should not find an association between innovation and other types of bribe payments. Murphy et al. (1993) also differentiate between public rent seeking (e.g., bribe payments to government officials) and private rent seeking (e.g., payments to private parties including theft, payments to the Mafia, etc.) and argue that innovators are particularly subject to public rent seeking, since they are more in need of government-supplied services than established firms. To explore this, we regress Protection Payments, which is the percentage of total sales that is used for protection payments to private parties such as the Mafia, on innovation and find no association between innovation and private payments. Consistent with Murphy et al.'s prediction, we do not find that innovators pay higher protection payments to private parties.

We conduct several robustness tests of our results. In Web Appendix B, we reestimate the specification in column 2 of Table 2 with a broader definition of innovation. Most firms in emerging markets are engaged in activities far from the technological frontier, and entrepreneurs innovate not just through original inventions but also by adopting new means of production, new products, and new forms of organization. Hence, we define the innovation process broadly by using firm responses to the survey questions on whether the firms had undertaken

\footnotetext{
${ }^{13}$ Most studies report corruption estimates as a percentage of costs (see Olken and Pande (2012)). Our estimate is as a percentage of sales revenue and is similar to Faccio (2006), who estimates corruption to be $2.3 \%$ of company value.
} 
any of the following innovative activities in the last 3 years: developed a new product line, upgraded an existing product line, introduced new technology that has substantially changed the way that the main product is produced, opened a new plant, agreed to a new joint venture with a foreign partner, obtained a new licensing agreement, outsourced a major production activity that was previously conducted in-house, or brought in-house a major production activity that was previously outsourced. The firm responses are coded as 0-1 (No-Yes) dummy variables for each of the questions. We construct two aggregate indices of innovation from the individual indicators: Aggregate Innovation Index is an aggregate index obtained by summing firm responses to all eight innovative activities in which the firm engages, and Core Innovation is an aggregate index obtained by summing firm responses to two activities: developed a major new product line and introduced new technology that has substantially changed the way that the main product is produced.

Web Appendix B shows that most other forms of innovation, such as upgrading a product line, introducing new technology, signing new joint ventures, and new licensing agreements, are associated with higher bribe payments. Core Innovation and the Aggregate Innovation Index are also positively and significantly (at the $1 \%$ level) associated with bribe payments. Very few firms in our sample engage in opening plants and changing sourcing decisions, and we find that those activities are not associated with significantly higher bribe payments. Replacing the linear specification with a logit specification using a dummy variable for bribes paid as the dependent variable, we find all types of innovation, including opening new plant and sourcing decisions, to be significantly associated with a higher probability of bribe payments.

In Web Appendix C, we consider alternate explanations that might be driving the relation between innovation and corruption by including additional control variables. First, in column 1, we examine if our results are being driven by location effects. Innovating firms may cluster around big cities in developing countries, which may also have more bureaucratic red tape and thus be associated with greater bribe payments than smaller cities. Our survey data classify the location of the establishment into Capital City, Other City of over 1 million population, City of 250,000-1 million, City of 50,000-250,000, and Town or Location with less than 50,000 population. Controlling for these location dummy variables in column 1 does not change our result that innovating firms pay more bribes than noninnovators.

Next, we examine if the link between innovation and corruption is influenced by the firm's customers. Firms selling output to large firms are more likely to innovate and also less likely to pay bribes since they are less likely to be paid in cash. So in column 2 of Web Appendix $\mathrm{C}$ we control for the percentage of domestic sales to large domestic firms with 300+ workers and find our results unchanged. In unreported checks, we obtain similar results if we examine a more detailed breakdown of firms' domestic sales to large domestic firms with 300+ workers, the government, state-owned enterprises, multinationals, affiliated subsidiary companies, and others such as small firms or individuals. We also find that controlling for the nature of suppliers and customers (whether they are domestic private firms, foreign private firms, or state-owned firms) makes no difference to the relation 
between innovation and corruption in our sample. Overall, we find strong evidence that bribe payments to government officials are tied to innovative projects, confirming that innovating firms are taxed for their innovation. These firms pay off government officials across various agencies to be able to get things done and innovate.

Firms in our survey were also asked to report how much of the contract value is typically expected in gifts or informal payments to secure the contract when firms in their industry do business with the government. In column 3 of Web Appendix C, we use this alternate bribe variable, Bribes in Government Contracts, as our dependent variable. We again find that innovating firms pay a larger percentage of their government contracts as bribes than do noninnovators, suggesting that innovating firms are particularly shaken down.

Since a large sample of our firms (62\%) report zero bribe payments, we use alternate estimation techniques other than OLS in columns 4 and 5 of Web Appendix $\mathrm{C}$ to address any concerns of the large mass of zeros in our data. In column 4, we use logit regressions, where a dummy variable takes a value of 1 if firm reported paying bribes, and 0 otherwise. We find that the log odds of having to pay bribes increases by 0.310 for innovators compared to noninnovators. Alternatively, in terms of odds ratios, the odds of having to pay bribes are 1.36 times higher for innovating firms than for noninnovators. While all our results remain unchanged, we do not use this for our main specification, since we would lose the variation in percentage of bribe payments by dichotomizing the bribe payments variable.

In column 5 of Web Appendix $\mathrm{C}$, we treat this as a corner solution model and use a two-limit Tobit model to account for the variable Bribes taking on the value of 0 with positive probability and being a continuous random variable over strictly positive values. ${ }^{14}$ We once again find our results unchanged. Being an innovator increases the probability that the firm pays bribes as well as the percentage of bribe payments conditional on paying bribes. We prefer the linear regression specification to Tobit, since we use country fixed effects with clustered errors, which biases parameter estimates in nonlinear models such as Tobit. ${ }^{15}$

\section{A. BEEPS Sample}

In this section, we undertake further robustness checks to confirm that innovative firms are indeed victimized by corruption, using data for a smaller

\footnotetext{
${ }^{14}$ Note that we do not have a censoring issue, so it is not the case that we do not observe bribe payments above or below some value.

${ }^{15}$ An alternative to the Tobit model is the hurdle model, which allows the decision of Bribes $>0$ versus Bribes $=0$ to be separate from the decision of how much Bribes given that Bribes $>0$. The hurdle model is a two-stage model where in the first stage we look at the determinants of the probability of payment of bribes, and in the second stage we look at the determinants of the amount of bribes. Our first-stage results from the hurdle model (unreported) confirm that innovators are more likely to pay bribes than noninnovators. Due to the lack of convergence in maximum likelihood (ML) estimation in the second stage, we are unable to obtain predictions on innovators and the level of bribe payments. Since Bribes are reported as a fraction of sales paid out as bribes and are restricted to the unit interval $[0,1]$, we also estimated a fractional response model using the fractional logit method proposed by Papke and Wooldridge (1996). We once again find that innovators pay more bribes than noninnovating firms.
} 
sample of 27 Central and Eastern European countries (BEEPS Sample). The BEEPS data have information on profit margins as well as additional measures of bribe payments. When we reestimate our regressions, controlling for profit margin in the BEEPS sample as in column 1 of Panel A of Table 3, we find that profit margin is not significant, and innovating firms still pay more bribes than noninnovators. For the same set of countries, we have surveys in 2002 that also have data on profit margin, and in column 2 of Panel A we again find that profit margin by itself is not significantly associated with bribe payments, whereas innovation is. In unreported tests, we find that past profitability, both in 1999 and 2001, is significantly associated with bribe payments, but controlling for past profitability, innovation is still significantly associated with increased bribe payments.

In columns 3-6 of Panel A of Table 3, we check whether our results are robust to the use of alternate bribe variables. The 2002 and 2005 BEEPS have two other questions on bribes that could serve as alternate dependent variables. Firms were asked to report on a scale of 1 to 6 whether it is common for firms in their line of business to have to pay some irregular additional payments/gifts to "get things done" with regard to customs, taxes, licenses, regulations, services, etc., with 1 being Never and 6 being Always. In addition, firms were asked to report on a scale of 1 to 6 whether firms in their line of business usually know in advance about how much this "additional payments/gifts" is, with 1 being Never and 6 being Always. Using either of these alternate dependent variables, Bribes_Common and Bribes_Known,${ }^{16}$ we find our results unchanged: Innovating firms are more likely to say that it is common to pay bribes and to also report knowing how much this additional bribe payment is. This is consistent with our interpretation that, in our sample, corruption is a fee imposed on firms by government employees.

In Panel B of Table 3, we exploit the panel component of the BEEPS data, where 1,436 firms that were surveyed in the year 2002 were surveyed again in 2005. We run regressions with firm fixed effects to examine if the relation between innovation and bribes holds once we control for unobserved heterogeneity at the firm level. ${ }^{17}$ However, since Innovator is a dummy variable, the power in these regressions is weak because identification is being driven off only the firms that did not innovate before and now innovate or those that innovated before and do not innovate now. As control variables, we use capacity utilization and profit margins that vary over time, and as dependent variables, we use the three measures of bribes available in the BEEPS sample: Bribes, Bribes_Common, and Bribes_Known.

\footnotetext{
${ }^{16}$ We treat the Likert-scale measures as ordinal data and use OLS, since Menard (1995) suggests that a linear regression is appropriate with ordinal dependent variables that have a large number of categories if we treat the variables as though they were measured on an interval scale. In the sociology and marketing literature, where use of ordinal variables from survey data is ubiquitous, it is common practice to treat ordinal variables as being continuous and to use OLS estimation when the number of outcomes for the categorical dependent variable is greater than 4 . The assumption behind this is that when the number of cutoff points is greater than 4, they may be considered approximately the same distance from each other.

${ }^{17}$ Since we have only 2 years of data, the regression with fixed effects is the same as the first difference estimator.
} 
TABLE 3

\section{Corruption as a Tax on Innovation: BEEPS Sample}

The regression model in Panel A is Bribes/Bribes_Common/Bribes_Known $=\alpha+\beta_{1}$ Innovator $+\beta_{2}$ Capacity Utilization $+\beta_{3}$ Firm Size dummies $+\beta_{4}$ Family Owned dummy $+\beta_{5}$ Legal Status dummies $+\beta_{6}$ Age $+\beta_{7}$ Foreign Ownership dummy $+\beta_{8}$ Exporter dummy $+\beta_{9}$ Industry Sector dummies $+\beta_{10}$ Year dummies $+\beta_{11}$ Country dummies $+\beta_{12}$ Sales Growth $+\epsilon$. The regression model in Panel B is Bribes/Bribes_Common/Bribes_Known $=\alpha+\beta_{1}$ Innovator $+\beta_{2}$ Capacity Utilization $+\beta_{3}$ Profit Margin $+\beta_{4} \log (\mathrm{GDP})+\beta_{5} \log (\mathrm{GDP} /$ Capita $)+\beta_{6}$ Inflation $+\beta_{7}$ GDP/Capita growth $+\beta_{8}$ Firm dummies $+\epsilon$. Bribes is the percentage of annual sales value that a typical firm spends on gifts or informal payments to public officials to "get things done" with regard to customs, taxes, licenses, regulations, services, etc. Bribes_Common is firms' response to the question whether it is common for firms in their line of business to have to pay some irregular "additional payments/gifts" to get things done with regard to customs, taxes, licenses, regulations, services, etc. The variable is scaled 1 to 6 , with 1 being Never and 6 being Always. Bribes_Known is the firms' response to the question whether firms in their line of business usually know in advance about how much this "additional payment/gift" is. The variable is scaled 1 to 6 , with 1 being Never and 6 being Always. Innovator is a dummy variable that takes the value of 1 if the firm developed a new product line, and 0 otherwise. Profit Margin is defined as the margin by which sales price exceeds operating costs. Capacity Utilization is defined as the amount of output actually produced relative to the maximum amount that could be produced with the firm's existing machinery and equipment and regular shifts. Firm Size dummies take values 1 to 3 for Small firms (1-19 employees), Medium firms (20-99 employees), and Large firms ( $>100$ employees), respectively. Family Owned dummy takes the value of 1 if the largest shareholder is an individual or family. Legal Status dummies consist of dummy variables for the following legal forms: Corporation, Partnership, Cooperative, Sole Proprietorship (omitted category), and Other Legal Status. Age is the year of the survey - year the firm was established. Foreign Ownership is a dummy variable that takes the value of 1 if the firm is foreign owned, and 0 otherwise. Exporter is a dummy variable that takes the value of 1 if the firm is an exporter, and 0 if it is a nonexporter. Industry Sector dummies are 5 industry sector dummy variables for Agro-Industry, Manufacturing, Construction, Services, and Other. $\log ($ GDP) is the logarithm of GDP in constant 2000 US\$. $\log ($ GDP/Capita) is the logarithm of GDP/Capita in constant 2000 US\$. GDP growth is the annual percentage growth in GDP, and Inflation is the annual percentage growth in GDP deflator. All country-level variables are sourced from World Development Indicators. The regressions in Panel A are estimated using OLS with standard errors clustered at the country level. The regressions in Panel B are estimated using firm fixed effects with standard errors clustered at the firm level. The adjusted $R^{2}$ s in Panel $\mathrm{B}$ are modified to reflect the contribution of the firm-level effects. All variables and their sources are described in Web Appendix D. ${ }^{a},{ }^{b}$, and ${ }^{C}$ indicate significance at the $1 \%, 5 \%$, and $10 \%$ levels, respectively.

Panel A. BEEPS Sample

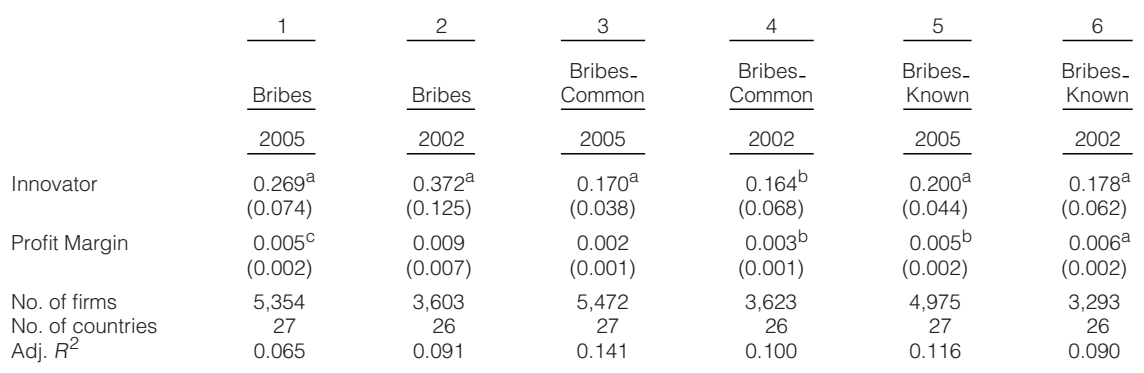

Panel B. BEEPS Panel Regressions with Firm Fixed Effects

\begin{tabular}{|c|c|c|c|}
\hline & 1 & 2 & 3 \\
\hline & Bribes & $\begin{array}{c}\text { Bribes_ } \\
\text { Common }\end{array}$ & $\begin{array}{l}\text { Bribes_ } \\
\text { Known }\end{array}$ \\
\hline Innovator & $\begin{array}{c}0.013 \\
(0.218)\end{array}$ & $\begin{array}{c}0.304^{a} \\
(0.103)\end{array}$ & $\begin{array}{c}0.348^{\mathrm{a}} \\
(0.131)\end{array}$ \\
\hline Profit Margin & $\begin{array}{c}0.002 \\
(0.006)\end{array}$ & $\begin{array}{c}-0.002 \\
(0.003)\end{array}$ & $\begin{array}{c}0.003 \\
(0.004)\end{array}$ \\
\hline Capacity Utilization & $\begin{array}{c}-0.006 \\
(0.006)\end{array}$ & $\begin{array}{c}-0.003 \\
(0.003)\end{array}$ & $\begin{array}{c}-0.004 \\
(0.003)\end{array}$ \\
\hline Constant & $\begin{array}{r}1.872^{\mathrm{a}} \\
(0.523)\end{array}$ & $\begin{array}{l}2.680^{\mathrm{a}} \\
(0.205)\end{array}$ & $\begin{array}{c}2.703^{a} \\
(0.258)\end{array}$ \\
\hline $\begin{array}{l}\text { No. of obs. } \\
\text { No. of firms } \\
\text { Adj. } R^{2}\end{array}$ & $\begin{array}{l}2,244 \\
1,339 \\
0.197\end{array}$ & $\begin{array}{l}2,256 \\
1,339 \\
0.293\end{array}$ & $\begin{array}{l}2,029 \\
1,273 \\
0.283\end{array}$ \\
\hline
\end{tabular}

Column 1 of Panel B in Table 3 shows that innovation is positive in the Bribes equation but not significant (though it may be noted that the sample size is greatly reduced compared to full sample regressions, and firms that never innovate or those that always innovate are not contributing to the identification here, reducing 
the power of the regression). ${ }^{18}$ Columns 2 and 3 show that the innovation coefficient is positive and significant in the Bribes_Common and Bribes_Known regressions. Our results are robust to including time-varying country variables such as $\log ($ GDP/Capita), Growth of GDP/Capita, and Inflation. Overall, the table suggests that controlling for unobserved firm heterogeneity, differences in innovation rates are positively associated with differences in bribe payments.

\section{B. Country Effects}

In this section, we replace country fixed effects with country-level variables to explore if the tax on innovation is more severe in certain countries than in others. In all the regressions, we control for basic country characteristics, including $\log (\mathrm{GDP}), \log (\mathrm{GDP} / \mathrm{Capita})$, GDP growth, and Inflation. Here, $\log$ (GDP) is the $\log$ of gross domestic product in constant $2000 \mathrm{US} \$, \log$ (GDP/Capita) is the log of gross domestic product/capita in constant 2000 US\$, GDP growth is the annual percentage growth in GDP, and Inflation is measured by the annual percentage growth rate of the GDP deflator.

In column 1 of Table 4, we interact the Innovator dummy with $\log$ (GDP/ Capita) and find the interaction term to be negative and significant, suggesting that innovators pay less bribes in more-developed countries. In column 2, we investigate if innovators are greater targets of public corruption in countries that have more bureaucratic regulations associated with operating a business. As a measure of bureaucratic regulation, we use Number of Procedures to Start a Business from the World Bank Doing Business Indicators database, which identifies the number of procedures to legally start and operate a company. As expected, the interaction term in column 2 shows that innovators in countries with more bureaucratic regulations pay more bribes.

In columns 3-6 of Table 4, we interact the Innovator dummy with the following dimensions of the World Bank Governance Indicators (Kaufmann, Kraay, and Mastruzzi (2009)): Government Effectiveness, which captures perceptions of the quality of public services, quality of civil service, and the degree of its independence from political pressures, the quality of policy formulation and implementation, and the credibility of the government's commitment to such policies; Regulatory Quality, which captures perceptions of the ability of the government to formulate and implement sound policies and regulations that permit and promote private sector development; Rule of Law, which captures perceptions of the extent to which agents have confidence in and abide by the rules of society, and in particular the quality of contract enforcement, property rights, the police, and the courts, as well as the likelihood of crime and violence; and Control of Corruption, which captures perceptions of the extent to which public power is exercised for private gain, including both petty and grand forms of corruption, as well as "capture" of the state by elites and private interests. All the governance indicators

\footnotetext{
${ }^{18}$ The number of firms is less than 1,436 once we drop firms with more than $50 \%$ state ownership and capacity utilization rates in excess of $150 \%$. The adjusted $R^{2}$ values in Table 3 reflect the contribution of the firm effects (as obtained from a regression with dummy variables for each firm).
} 
TABLE 4

\section{Corruption and Innovation: Country Effects}

The regression model in columns 1-6 is Bribes $=\alpha_{0}+\beta_{1}$ Innovator $+\beta_{2} \log ($ GDP $)+\beta_{3} \log ($ GDP/Capita $)+\beta_{4}$ GDP Growth $+\beta_{5}$ Inflation $+\beta_{6}$ Country Effect $+\beta_{7}$ Innovator $\times$ Country Effect $+\beta_{8}$ Capacity Utilization $+\beta_{9}$ Firm Size dummies + $\beta_{10}$ Family Owned dummy $+\beta_{11}$ Legal Status dummies $+\beta_{12}$ Age $+\beta_{13}$ Foreign Ownership dummy $+\beta_{14}$ Exporter dummy $+\beta_{15}$ Industry Sector dummies $+\beta_{16}$ Year dummies $+\epsilon$. Country Effect is one of the following variables: Number of Procedures to Start a Business is the number of procedures required to register a firm from the World Bank Doing Business Indicators. Government Effectiveness captures perceptions of the quality of public services, the quality of civil service and the degree of its independence from political pressures, the quality of policy formulation and implementation, and the credibility of the government's commitment to such policies. Regulatory Quality captures perceptions of the ability of the government to formulate and implement sound policies and regulations that permit and promote private sector development. Rule of Law captures perceptions of the extent to which agents have confidence in and abide by the rules of society, and in particular the quality of contract enforcement, property rights, the police, and the courts, as well as the likelihood of crime and violence. Control of Corruption captures perceptions of the extent to which public power is exercised for private gain, including both petty and grand forms of corruption, as well as "capture" of the state by elites and private interests. Government Effectiveness, Regulatory Quality, Rule of Law, and Control of Corruption are averages from 2002 to 2005 and are sourced from the World Bank Governance Indicators (Kaufmann et al. (2009)). log(GDP) is the logarithm of gross domestic product in constant 2000 US\$ from World Development Indicators. log(GDP/Capita) is the logarithm of gross domestic product/capita in constant 2000 US\$ from World Development Indicators. GDP Growth is the annual percentage growth in GDP from World Development Indicators. Inflation is the GDP deflator (\%) from World Development Indicators. Bribes is the percent of annual sales value that a typical firm spends on gifts or informal payments to public officials to "get things done" with regard to customs, taxes, licenses, regulations, services, etc. Innovator is a dummy variable that takes the value of 1 if the firm developed a new product line, and 0 otherwise. Capacity Utilization is defined as the amount of output actually produced relative to the maximum amount that could be produced with the firm's existing machinery and equipment and regular shifts. Firm Size dummy variables take values 1 to 3 for Small firms (1-19 employees), Medium firms (20-99 employees), and Large firms ( $\geq 100$ employees), respectively. Family Owned dummy takes the value of 1 if the largest shareholder is an individual or family. Legal Status dummies consist of dummy variables for the following legal forms: Corporation, Partnership, Cooperative, Sole Proprietorship (omitted category), and Other Legal Status. Age is the year of the survey - year the firm was established. Foreign Ownership is a dummy variable that takes the value of 1 if the firm is foreign owned, and 0 otherwise. Exporter is a dummy variable that takes the value of 1 if the firm is an exporter, and 0 if it is a nonexporter. Sector dummies are 5 industry sector dummy variables for Agro-Industry, Manufacturing, Construction, Services, and Other. The regressions are estimated using OLS with standard errors clustered at the country level. All variables and their sources are described in Web Appendix D. ${ }^{a},{ }^{b}$, and ${ }^{\mathrm{C}}$ indicate significance at the $1 \%, 5 \%$, and $10 \%$ levels, respectively.

$\log (G D P)$

$\log (G D P / C a p i t a)$

GDP Growth

Inflation

Innovator

Innovator $\times \log ($ GDP/Capita)

No. of Procedures to Start a Business

\begin{tabular}{c}
$\frac{1}{\text { Bribes }}$ \\
\hline-0.091 \\
$(0.070)$ \\
$-0.237^{\mathrm{b}}$ \\
$(0.117)$ \\
0.011 \\
$(0.032)$ \\
-0.003 \\
$(0.010)$ \\
$1.243^{\mathrm{b}}$ \\
$(0.483)$ \\
$-0.113^{\mathrm{c}}$ \\
$(0.058)$
\end{tabular}

Innovator $\times$ No. of Procedures

to Start a Business

Government Effectiveness

Innovator $\times$ Government Effectiveness

Regulatory Quality

\begin{tabular}{c}
2 \\
\hline Bribes \\
\hline$-0.144^{\mathrm{C}}$ \\
$(0.080)$ \\
-0.186 \\
$(0.142)$ \\
0.010 \\
$(0.028)$ \\
-0.002 \\
$(0.010)$ \\
-0.173 \\
$(0.321)$ \\
\\
\\
0.061 \\
$(0.037)$ \\
$0.050^{\mathrm{C}}$ \\
$(0.029)$
\end{tabular}

$0.050^{c}$
$(0.029)$

$-0.709^{\mathrm{a}}$

(0.239)

$-0.274^{\mathrm{a}}$

(0.091)

$-0.231^{\mathrm{a}}$

$(0.075)$

Rule of Law

Innovator $\times$ Rule of Law

Control of Corruption

Innovator $\times$ Control of Corruption

Innovator $\times$ Regulatory Quality

\begin{tabular}{|c|c|c|}
\hline 4 & 5 & 6 \\
\hline Bribes & Bribes & Bribes \\
\hline $\begin{array}{c}-0.102 \\
(0.072)\end{array}$ & $\begin{array}{r}-0.103 \\
(0.071)\end{array}$ & $\begin{array}{r}-0.112 \\
(0.071)\end{array}$ \\
\hline $\begin{array}{c}-0.079 \\
(0.168)\end{array}$ & $\begin{array}{c}-0.074 \\
(0.142)\end{array}$ & $\begin{array}{c}-0.062 \\
(0.147)\end{array}$ \\
\hline $\begin{array}{c}0.008 \\
(0.032)\end{array}$ & $\begin{array}{c}0.000 \\
(0.035)\end{array}$ & $\begin{array}{r}-0.004 \\
(0.036)\end{array}$ \\
\hline $\begin{array}{c}-0.016 \\
(0.011)\end{array}$ & $\begin{array}{r}-0.010 \\
(0.011)\end{array}$ & $\begin{array}{r}-0.008 \\
(0.011)\end{array}$ \\
\hline $\begin{array}{c}0.415^{a} \\
(0.077)\end{array}$ & $\begin{array}{c}0.338^{a} \\
(0.071)\end{array}$ & $\begin{array}{r}0.342^{2} \\
(0.071)\end{array}$ \\
\hline
\end{tabular}

$-0.307$

(0.205)

$-0.251^{a}$

(0.081) 


\begin{tabular}{|c|c|c|c|c|c|c|}
\hline \multicolumn{2}{|c|}{ Corruption and Innovation: Country Effects } & & & & & \\
\hline & 1 & 2 & 3 & 4 & 5 & 6 \\
\hline & Bribes & Bribes & Bribes & Bribes & Bribes & Bribes \\
\hline Constant & $\begin{array}{c}6.160^{\mathrm{a}} \\
(1.281)\end{array}$ & $\begin{array}{c}6.371^{\mathrm{a}} \\
(1.240)\end{array}$ & $\begin{array}{c}3.281^{b} \\
(1.411)\end{array}$ & $\begin{array}{c}5.320^{a} \\
(1.327)\end{array}$ & $\begin{array}{c}5.266^{\mathrm{a}} \\
(1.416)\end{array}$ & $\begin{array}{r}5.307^{a} \\
(1.429)\end{array}$ \\
\hline $\begin{array}{l}\text { No. of firms } \\
\text { No. of countries } \\
\text { Adj. } R^{2}\end{array}$ & $\begin{array}{c}25,376 \\
55 \\
0.033\end{array}$ & $\begin{array}{c}24,969 \\
54 \\
0.034\end{array}$ & $\begin{array}{c}25,332 \\
54 \\
0.036\end{array}$ & $\begin{array}{c}25,332 \\
54 \\
0.034\end{array}$ & $\begin{array}{c}25,376 \\
55 \\
0.034\end{array}$ & $\begin{array}{c}25,376 \\
55 \\
0.034\end{array}$ \\
\hline
\end{tabular}

are averaged over 2002 to 2005 (the survey years in our sample) and range from -2.5 to 2.5 , with higher values indicating better governance.

Columns 3-6 of Table 4 show that the interaction coefficients of the Innovator dummy and the governance indicators are all negative and significant, suggesting that innovators are particularly shaken down in countries with weak rule of law, poor regulatory quality, high corruption, and poor quality of public services as measured by government ineffectiveness. Overall, Table 4 shows that innovating firms pay a larger percentage of their sales as bribes than noninnovators in countries with more bureaucratic regulations and weak governance.

\section{Implications}

In this section, we explore alternate explanations and further implications of the association between innovation and corruption discussed in Table 2.

\section{A. Innovators and Their Interactions with Government}

We first investigate whether there is evidence that innovators that pay bribes receive preferential treatment from government officials, such as reductions in the time spent obtaining regulatory approvals or better services. Any such private benefits would have to be offset against the private costs of bribes to innovating firms.

Our surveys provide detailed information on the service interruptions experienced by firms, the delays in obtaining different licenses required for operation of their business, and the time spent dealing with bureaucracy. Some innovators spend more time dealing with government regulations, since they are more in need of government services, and hence these innovators get preyed upon more often. Therefore, we compare the government interactions of innovators that pay bribes and innovators that do not pay bribes. As a comparison, we also study noninnovators that pay bribes and noninnovators that do not pay bribes.

In columns 1 and 2 of Panel A of Table 5, we look at the average number of days in the last year that innovators spent in inspections and mandatory meetings with officials of different government agencies in the context of regulating their business. We find that innovators that pay bribes (col. 2) spend significantly more time in dealing with officials from all agencies than innovators that do not pay bribes, except in the case of fire and building safety and environmental agencies, where the differences are not significant. Similarly, columns 3 and 4 show 
that noninnovators that pay bribes also spend more time interacting with different government agencies than noninnovators that do not pay bribes. Across all agencies, we find that innovators that pay bribes spent an average of 15.39 days in the past year dealing with inspections and mandatory meetings with government officials in all agencies, which is significantly higher than innovators that do not pay bribes (11.08), noninnovators that do not pay bribes (7.21), and noninnovators that pay bribes (11.23). As an alternate measure, we examine the percentage of senior management time in a week that is spent in dealing with requirements imposed by government regulations, including dealings with officials, completing forms, etc., and once again we find that the management in innovating firms that pay bribes spends the highest percentage of their time in a week $(9.85 \%)$ dealing with bureaucracy than in the other three categories. Overall, Panel A shows that innovators spend more time dealing with government regulations and the bureaucracy. Thus, government officials have greater opportunities to extract payments from them than from other types of firms.

\section{TABLE 5}

\section{Innovators and Their Interactions with Bureaucracy}

Table 5 shows interactions between innovators and the government. Columns 1 and 2 in each panel present mean comparison tests between innovators that pay bribes and innovators that do not pay bribes. Columns 3 and 4 in each panel present mean comparison tests between noninnovators that pay bribes and noninnovators that do not pay bribes. Innovators that pay bribes are firms that report new product innovation and pay a percentage of their sales as gifts or informal payments to public officials. Innovators that do not pay bribes are firms that report new product innovation and report paying no bribes to public officials. In Panel A, Tax Inspectorate, Labor \& Social Security, Fire \& Building Safety, Sanitation/Epidemiology, Municipal Police, Environmental, and All Agencies are the number of days spent in inspections and mandatory meetings with officials in each of the corresponding agencies. The \% of Management Time in a Week Spent Dealing with Regulations is the percentage of senior management time spent in dealing with requirements imposed by government regulations (e.g. taxes, customs, labor regulations, licensing, and registration) including dealings with officials, completing forms, etc. In Panel B, Power Outages, Insufficient Water Supply, Unavailable Telephone Service, and Transport Failures are the number of days the firm experienced the corresponding service interruptions in the last year. In Panel C, Telephone Connection and Electrical Connection are the actual delay or wait time in number of days for obtaining the corresponding service or approval from the day the firm applied for the service. All variables and their sources are described in Web Appendix D. $\mathrm{a}, \mathrm{b}$, and ${ }^{\mathrm{C}}$ indicate significance at the $1 \%, 5 \%$, and $10 \%$ levels, respectively.

\begin{tabular}{|c|c|c|}
\hline 1 & 2 & 3 \\
\hline $\begin{array}{l}\text { Innovators } \\
\text { that Do Not }\end{array}$ & $\begin{array}{c}\text { Innovators } \\
\text { that }\end{array}$ & $\begin{array}{c}\text { Noninnovators } \\
\text { that Do Not }\end{array}$ \\
\hline Pay Bribes & Pay Bribes & Pay Bribes \\
\hline
\end{tabular}

\begin{tabular}{c}
$\frac{4}{\text { Noninnovators }}$ \\
that Pay \\
Bribes \\
\hline
\end{tabular}

$\underline{\text { Panel A. Days Spent Interacting with Different Government Agencies Last Year }}$

Tax Inspectorate

Labor \& Social Security

Fire \& Building Safety

Sanitation/Epidemiology

Municipal Police

Environmental

All Agencies

$\%$ of Management Time in a Week

Spent Dealing with Regulations

Panel B. Days of Service Interruptions Last Year

Power Outages

Insufficient Water Supply

Unavailable Telephone Service

Transport Failures

$\begin{array}{cc}3.57 & 5.27^{\mathrm{a}} \\ 2.19 & 2.88^{\mathrm{a}} \\ 1.6 & 1.72 \\ 2.59 & 3.06^{\mathrm{b}} \\ 1.55 & 2.09^{\mathrm{a}} \\ 1.63 & 1.87 \\ 11.08 & 15.39^{\mathrm{a}} \\ 6.5 & 9.85^{\mathrm{a}}\end{array}$

Panel C. Delays/Wait Time (in days) for Obtaining Licenses and Permits (except for telephone and electricity, for the rest, innovators and noninnovators have $<1,000$ observations)

\begin{tabular}{lllll}
\hline Telephone Connection & 19.3 & $29.19^{\mathrm{a}}$ & 17.76 & 18.88 \\
Electrical Connection & 12.23 & $16.29^{\mathrm{a}}$ & 10.75 & 11.33 \\
\hline
\end{tabular}


In Panel B of Table 5, we examine the mean number of days that firms experience service interruptions due to power outages, insufficient water supply, unavailable telephone service, and transport failures. In columns 1 and 2, we present a test of means between innovators that pay bribes and innovators that do not pay bribes, and in columns 3 and 4, we present a test of means between noninnovators that pay bribes and noninnovators that do not pay bribes. Columns 1 and 2 of Panel B show that innovating firms that pay bribes on average lose 17.09, 10.52 , and 5.43 days, respectively, due to power outages, insufficient water supply, and unavailable telephone service, which are all significantly larger than the $11.21,6.24$, and 2.59 days, respectively, lost by innovators that do not pay bribes. Columns 3 and 4 also show that noninnovators that pay bribes also have greater service interruptions than noninnovators that do not pay bribes. When we compare across columns 1-4 in Panel B, we see that innovators that pay bribes are the worst affected. In Panel C, we find that innovators that pay bribes experience significantly longer delays in obtaining a mainline telephone connection and an electrical connection compared to innovators that do not pay bribes, as well as noninnovators that pay bribes. ${ }^{19}$

Note that while these results suggest that innovating firms that pay bribes are not benefiting through reduced service interruptions, and may be extorted by actual service interruptions, we are cautious in our interpretations, since we do not have information on the timing of the bribe payments relative to that of the service interruptions. Our findings provide further suggestive evidence that the type of corruption we analyze serves as a tax on innovation rather than benefiting the firms in any specific way. Our results are consistent with Kaufmann et al. (2008), who analyze survey data from officials of 13 government agencies in Peru that are providers of essential services and find that corruption reduces the supply of basic public services.

\section{B. Do Innovators Participate in Other Illegal Behavior?}

We next examine whether innovation is associated with tax evasion, a form of illegality that directly benefits the perpetrating firm. It could be that innovating firms are particularly prone to illegal behavior and hence participate in other nefarious activities, such as tax evasion.

In columns 1 and 2 of Table 6, we examine the relation between innovation and tax evasion. In column 1 , we find innovation to be weakly associated with tax evasion at the $10 \%$ level. In column 2, we use the BEEPS sample, which allows us to control for firms' profit margins. We find no association between innovation and tax evasion. In unreported tests, we also find that using the panel component of BEEPS and running firm fixed effect regressions, we find no association between the changes in innovation rates and the changes in tax evasion from 2002 to 2005.

\footnotetext{
${ }^{19}$ In unreported statistics, we also find that innovators that pay bribes report longer delays or wait times in obtaining water connection, construction permits, import licenses, and operating licenses than firms in the other three categories. We do not report these in Table 5, since the sample sizes for firms reporting data on water connections, construction permits, and import and operating licenses are less than 500 .
} 
TABLE 6

Innovators and Other Illegal Behavior

The regression model in columns 1-4 is Illegal Behavior $=\alpha_{0}+\beta_{1}$ Bribes $+\beta_{2}$ Innovator $+\beta_{3}$ Innovator $\times$ Bribes $+\beta_{4}$ Profit Margin $+\beta_{5}$ Capacity Utilization $+\beta_{6}$ Firm Size dummies $+\beta_{7}$ Family Owned dummy $+\beta_{8}$ Legal Status dummies $+\beta_{9}$ Age + $\beta_{10}$ Foreign Ownership dummy $+\beta_{11}$ Exporter dummy $+\beta_{12}$ Industry Sector Dummies $+\beta_{13}$ Year dummies $+\beta_{14}$ Country dummies $+\epsilon$. Our measure of illegal behavior is Tax Evasion, which is the percentage of annual sales that a typical firm underreports for tax purposes. Bribes is the percentage of annual sales value that a typical firm spends on gifts or informal payments to public officials to "get things done" with regard to customs, taxes, licenses, regulations, services, etc. Innovator is a dummy variable that takes the value of 1 if the firm developed a new product line, and 0 otherwise. Capacity Utilization is defined as the amount of output actually produced relative to the maximum amount that could be produced with the firm's existing machinery and equipment and regular shifts. Firm Size dummies take values 1 to 3 for Small firms (1-19 employees), Medium firms (20-99 employees), and Large firms ( $\geq 100$ employees), respectively. Family Owned dummy takes the value of 1 if the largest shareholder is an individual or family. Legal Status dummies consist of dummy variables for the following legal forms: Corporation, Partnership, Cooperative, Sole Proprietorship (omitted category), and Other Legal Status. Age is the year of the survey - year the firm was established. Foreign Ownership is a dummy variable that takes the value of 1 if the firm is foreign owned, and 0 otherwise. Exporter is a dummy variable that takes the value of 1 if the firm is an exporter, and 0 if it is a nonexporter. Industry Sector dummies are 5 industry sector dummy variables for Agro-Industry, Manufacturing, Construction, Services, and Other. The regressions in columns 1-4 are estimated using OLS with standard errors clustered at the country level. All variables and their sources are described in Web Appendix D. $\mathrm{a}, \mathrm{b}$, and ${ }^{\mathrm{c}}$ indicate significance at the $1 \%, 5 \%$, and $10 \%$ levels, respectively.

\begin{tabular}{|c|c|c|c|c|}
\hline & 1 & 2 & 3 & 4 \\
\hline & Full Sample & $\begin{array}{c}2005 \text { BEEPS } \\
\text { Sample }\end{array}$ & Full Sample & $\begin{array}{c}2005 \text { BEEPS } \\
\text { Sample }\end{array}$ \\
\hline & Tax Evasion & Tax Evasion & Tax Evasion & Tax Evasion \\
\hline Innovator & $\begin{array}{c}0.973^{\mathrm{C}} \\
(0.496)\end{array}$ & $\begin{array}{c}0.808 \\
(0.490)\end{array}$ & $\begin{array}{c}0.964^{\mathrm{C}} \\
(0.532)\end{array}$ & $\begin{array}{c}0.376 \\
(0.590)\end{array}$ \\
\hline Bribes & & & $\begin{array}{c}0.580^{a} \\
(0.092)\end{array}$ & $\begin{array}{c}1.297^{a} \\
(0.220)\end{array}$ \\
\hline Innovator $\times$ Bribes & & & $\begin{array}{r}-0.140 \\
(0.118)\end{array}$ & $\begin{array}{c}0.114 \\
(0.180)\end{array}$ \\
\hline No. of firms & 28,375 & 7,953 & 24,179 & 7,078 \\
\hline No. of countries & 59 & 27 & 57 & 27 \\
\hline Adj. $R^{2}$ & 0.197 & 0.114 & 0.188 & 0.124 \\
\hline
\end{tabular}

Overall, columns 1 and 2 of Table 6 do not support the conjecture that innovators are perpetrators engaging in all types of criminal activities.

Even if innovative firms were not prone to illegal behavior, the experience of being victimized by government officials might affect the firm's compliance with government rules in other contexts, more specifically, the tax collection system. Thus, the firms could try to recoup some of their losses by evading taxes. So we would expect innovating firms that pay more bribes to also evade more taxes. There are several reasons to expect that firms shaken down by government officials respond by greater underreporting of income to the tax authorities. Much research on taxpayer morale in public finance ${ }^{20}$ suggests that compliance with tax regulation rests on a belief in the legitimacy of the tax process and trust in government. This work suggests that the firm is likely to evade taxes if the implicit contract between the government and the taxpayer is broken. ${ }^{21}$

\footnotetext{
${ }^{20}$ Taxpayers are more likely to refrain from cheating if they trust the government (Scholz and Lubell (1998), Scholz and Pinney (1995), and Torgler (2007)) and are satisfied with government performance (Spicer and Lundstedt (1976), Smith (1992), Alm, Jackson, and McKee (1992a), and Pommerehne, Hart, and Frey (1994)). Therefore, if, as suggested by the trust literature, bribes demanded by public officials are a signal to the firm that the government is dishonest, it leads to loss of trust in the government and thus to tax evasion.

${ }^{21}$ An emerging finance literature on trust emphasizes the importance of cultural norms and trust for economic exchange (e.g., Guiso, Sapienza, and Zingales (2008), Carlin, Dorabantu, and Viswanathan (2009)).
} 
While much of this literature rests on behavioral notions of fairness, several authors suggest that tax evasion may be a rational response to extortion by government officials. In an asymmetric information model, extortion of a bribe provides a signal to the firm that the government is dishonest and that there is a lower probability that the taxes will be used for services that the taxpayer implicitly expects. Several papers (e.g., Alm, McClelland, and Schulze (1992), Alm, Jackson, and McKee (1992a), (1992b), (1993), and Pommerehne et al. (1994)) show that this creates incentives for firms to evade taxes at the margin and use the saved funds to provide those services. ${ }^{22}$

We investigate if innovating firms that pay more bribes also evade more taxes in the full sample and the 2005 BEEPS sample, in columns 3 and 4 of Table 6, respectively. In both samples, we find no relation between innovation and tax evasion, but we do find a strong positive association between bribes and tax evasion. That is, firms that pay more bribes evade more taxes. Furthermore, the interaction between innovation and bribes is not significant, suggesting that there is no evidence that innovating firms that pay bribes in our sample also evade more taxes.

\section{Conclusion}

A key policy issue in development finance is to design institutions that promote innovation and economic growth. In many countries there is considerable illegality in the relations between government officials and firms. The very institutions designed to promote commerce and ensure a level playing field become platforms that permit state employees to hold up firms opportunistically, and certain types of firms such as innovators and entrepreneurs might be particularly vulnerable. In this paper, we use a sample of 25,000 firms in 57 countries to study how innovating firms are affected by corruption of public employees. We have the following main findings:

First, we find that innovating firms are more likely to pay bribes to government officials than firms that do not innovate. In addition, innovators with government contracts pay a greater percentage of the contract value as bribes than noninnovators. In a placebo test, we find no evidence that innovators engage in other bribe payments, such a protection payments to the Mafia. Thus, our results suggest that government corruption acts as a tax on firm innovation by increasing the costs to innovators. Our results are also consistent with the Murphy et al. (1993) hypothesis that government officials' predation, as opposed to private predation, is more costly to innovators. We also find that small, young, and individual- or family-owned firms pay more bribes than larger, older firms and firms with other ownership structures.

Second, we find that innovating firms pay more bribes than noninnovators in less-developed countries, and in countries with more bureaucratic regulations and weak governance. All our results are robust to controlling for potential omitted variable bias, firm profitability, and alternate measures of bribe payments.

\footnotetext{
${ }^{22}$ Thus, for example, extortion by police might cause a firm to doubt that the state will provide adequate protection from violent crime in future years and to evade taxes (using some of the saved funds to purchase private security).
} 
Our results are also robust to controlling for unobserved firm heterogeneity using firm fixed effects in a smaller sample of firms for which we have panel data. Taken together, these results point to the costs of corruption imposed on firms.

Third, we find no evidence that innovating firms that pay bribes receive better government services than innovating firms that do not pay bribes. Fourth, we find no evidence that innovating firms are more likely to engage in other forms of illegal behavior such as tax evasion. Thus, innovating firms are more likely to be victims of corruption and less likely to be perpetrators who cheat on their taxes.

More broadly, our results suggest that bribery of government officials has more complex consequences beyond that of a simple transaction between a corrupt official and a firm.

\section{References}

Acemoglu, D.; P. Aghion; and F. Zilibotti. "Distance to Frontier, Selection, and Economic Growth." Journal of the European Economic Association, 4 (2006), 37-74.

Acemoglu, D., and S. Johnson. "Unbundling Institutions." Journal of Political Economy, 113 (2005), 949-995.

Ades, A., and R. Di Tella. "The New Economics of Corruption: A Survey and Some New Results." Political Studies, 45 (1997), 496-516. Reprinted in Political Corruption, P. Heywood, ed. Oxford, UK: Blackwell Publishers (1997).

Aghion, P.; R. Burgess; S. Redding; and F. Zilibotti. "Entry Liberalization and Inequality in Industrial Performance." Journal of the European Economic Association, 3 (2005), 291-302.

Aghion, P., and S. Durlauf, eds. Handbook of Economic Growth. Amsterdam, Netherlands: NorthHolland Elsevier Publishers (2005).

Ahlin, C., and J. Pang. "Are Financial Development and Corruption Control Substitutes in Promoting Growth?" Journal of Development Economics, 86 (2008), 414-433.

Alm, J.; B. R. Jackson; and M. McKee. "Estimating the Determinants of Taxpayer Compliance with Experimental Data." National Tax Journal, 45 (1992a), 107-114.

Alm, J.; B. R. Jackson; and M. McKee. "Institutional Uncertainty and Taxpayer Compliance." American Economic Review, 82 (1992b), 1018-1026.

Alm, J.; B. R. Jackson; and M. McKee. "Fiscal Exchange, Collective Decision Institutions, and Tax Compliance.” Journal of Economic Behavior and Organization, 22 (1993), 285-303.

Alm, J.; G. H. McClelland; and W. D. Schulze. "Why Do People Pay Taxes?" Journal of Public Economics, 48 (1992), 21-48.

Ayyagari, M.; A. Demirgüç-Kunt; and V. Maksimovic. "How Important Are Financing Constraints? The Role of Finance in the Business Environment." World Bank Economic Review, 22 (2008a), 483-516.

Ayyagari, M.; A. Demirgüç-Kunt; and V. Maksimovic. "How Well Do Institutional Theories Explain Firms' Perceptions of Property Rights?” Review of Financial Studies, 21 (2008b), 1833-1871.

Ayyagari, M.; A. Demirgüç-Kunt; and V. Maksimovic. "Formal versus Informal Finance: Evidence from China.” Review of Financial Studies, 23 (2010), 3048-3097.

Ayyagari, M.; A. Demirgüç-Kunt; and V. Maksimovic. "Firm Innovation in Emerging Markets, Role of Finance and Governance." Journal of Financial and Quantitative Analysis, 46 (2011), 1545-1580.

Ayyagari, M.; A. Demirgüç-Kunt; and V. Maksimovic. "Financing in Developing Countries." In Handbook of the Economics of Finance, Vol. 2, G. M. Constantinides, M. Harris, and R. Stulz, eds. Amsterdam: Newnes Elsevier Publishers (2013).

Ayyagari, M.; A. Demirgüç-Kunt; and V. Maksimovic. "Who Creates Jobs in Developing Countries?" Small Business Economics, 43 (2014), 75-99.

Barth, J.; C. Lin; P. Lin; and F. Song. "Corruption in Bank Lending to Firms: Cross-Country Micro Evidence on the Beneficial Role of Competition and Information Sharing." Journal of Financial Economics, 91 (2009), 361-388.

Baumol, W. The Free-Market Innovation Machine: Analyzing the Growth Miracle of Capitalism. Princeton, NJ: Princeton University Press (2002).

Beck, T.; A. Demirgüç-Kunt; and V. Maksimovic. "Financial and Legal Constraints to Firm Growth: Does Firm Size Matter?” Journal of Finance, 60 (2005), 137-177.

Beck, T.; A. Demirgüç-Kunt; and V. Maksimovic. "Financing Patterns around the World: Are Small Firms Different?" Journal of Financial Economics, 89 (2008), 467-487. 
Berkowitz, D., and W. Li. "Tax Rights in Transition Economies: A Tragedy of the Commons?" Journal of Public Economics, 76 (2000), 369-397.

Carlin, B.; F. Dorabantu; and S. Viswanathan. "Public Trust, the Law and Financial Investment." Journal of Financial Economics, 92 (2009), 321-341.

Cull, R., and L. C. Xu. "Institutions, Ownership, and Finance: The Determinants of Profit Reinvestment among Chinese Firms.” Journal of Financial Economics, 77 (2005), 117-146.

De Soto, H. The Other Path: The Invisible Revolution in the Third World. New York: Harper Collins (1989).

Djankov, S.; R. La Porta; F. Lopez-de-Silanes; and A. Shleifer. "The Regulation of Entry.” Quarterly Journal of Economics, 117 (2002), 1-37.

Djankov, S.; R. La Porta; F. Lopez-de-Silanes; and A. Shleifer. "Courts.” Quarterly Journal of Economics, 118 (2003), 453-517.

Faccio, M. "Politically Connected Firms." American Economic Review, 96 (2006), 369-386.

Fisman, R., and J. Svensson. "Are Corruption and Taxation Really Harmful to Growth? Firm Level Evidence." Journal of Development Economics, 83 (2007), 63-75.

Frye T., and A. Shleifer. "The Invisible Hand and the Grabbing Hand." American Economic Review, 87 (1997), 354-358.

Graham, J. R., and C. Harvey. "The Theory and Practice of Corporate Finance: Evidence from the Field." Journal of Financial Economics, 60 (2001), 187-243.

Graham, J. R.; C. Harvey; and S. Rajgopal. "The Economic Implications of Corporate Financial Reporting." Journal of Accounting and Economics, 40 (2005), 3-73.

Grossman, G. M., and E. Helpman. "Quality Ladders in the Theory of Growth." Review of Economic Studies, 58 (1991), 43-61.

Guiso, L.; P. Sapienza; and L. Zingales. "Trusting the Stock Market.” Journal of Finance, 63 (2008), 2557-2600.

Hall, R. E., and C. I. Jones. "Why Do Some Countries Produce So Much More Output per Worker than Others?" Quarterly Journal of Economics, 114 (1999), 83-116.

Hazari, R. K. The Structure of the Corporate Private Sector: A Study of Concentration, Ownership and Control. Bombay: Asia Publishing House (1966).

Hellman, J. S.; G. Jones; and D. Kaufmann. "Seize the State, Seize the Day: State Capture and Influence in Transition Economies.” Journal of Comparative Economics, 31 (2003), 751-773.

Houston, J.; C. Lin; and Y. Ma. "Media Ownership, Concentration and Corruption in Bank Lending." Journal of Financial Economics, 100 (2011), 326-350.

Johnson, S.; D. Kaufmann; and P. Zoido-Lobaton. "Regulatory Discretion and Corruption." American Economic Review (Papers and Proceedings), 88 (1998), 387-392.

Kaufmann, D.; A. Kraay; and M. Mastruzzi. "Governance Matters VIII: Aggregate and Individual Governance Indicators, 1996-2008.” World Bank Policy Research Working Paper 4978 (2009).

Kaufmann, D.; J. Montoriol-Garriga; and F. Recanatini. "How Does Bribery Affect Public Service Delivery? Micro-Evidence from Service Users and Public Officials in Peru." World Bank Policy Research Working Paper 4492 (2008).

Klapper, L.; L. Laeven; and R. Rajan. "Entry Regulation as a Barrier to Entrepreneurship.” Journal of Financial Economics, 82 (2006), 591-629.

Mauro, P. “Corruption and Growth.” Quarterly Journal of Economics, 110 (1995), 681-712.

Menard, S. “Applied Logistic Regression Analysis.” Sage University Paper Series on Quantitative Applications in the Social Sciences, 07-106. Thousand Oaks, CA: Sage (1995).

Michalopoulos, S.; L. Laeven; and R. Levine. "Financial Innovation and Endogenous Growth.” NBER Working Papers 15356 (2009).

Murphy, K.; A. Shleifer; and R. Vishny. "Why Is Rent-Seeking So Costly to Growth?" American Economic Review, 83 (1993), 409-414.

Olken, B., and R. Pande. "Corruption in Developing Countries." Annual Review of Economics, 4 (2012), 479-509.

Papke, L. E., and J. M. Wooldridge. "Econometric Methods for Fractional Response Variables with an Application to 401(k) Plan Participation Rates.” Journal of Applied Econometrics, 11 (1996), 619-632.

Pommerehne, W.; A. Hart; and B. S. Frey. "Tax Morale, Tax Evasion and the Choice of Policy Instruments in Different Political Systems.” Public Finance, 49 (1994), 52-69.

Scholz, J. T., and M. Lubell. "Trust and Taxpayers: Testing the Heuristic Approach to Collective Action.” American Journal of Political Science, 42 (1998), 398-417.

Scholz, J. T., and N. Pinney. "Duty, Fear and Tax Compliance: The Heuristic Basis of Citizenship Behavior." American Journal of Political Science, 39 (1995), 490-512.

Schumpeter, J. A. The Theory of Economic Development. Cambridge, MA: Harvard University Press (1934). 


\section{Ayyagari, Demirgüç-Kunt, and Maksimovic 75}

Schumpeter, J. A. Capitalism, Socialism, and Democracy. New York: Harper and Brothers (1942).

Segerstrom, P. S. "Innovation, Imitation, and Economic Growth." Journal of Political Economy, 99 (1991), 807-827.

Shleifer, A., and R. W. Vishny. "Corruption.” Quarterly Journal of Economics, 108 (1993), 599-617.

Smith, K. W. "Reciprocity and Fairness: Positive Incentives for Taxpayer Compliance." In Why People Pay Taxes, J. Slemrod, ed. Ann Arbor, MI: University of Michigan Press (1992).

Spicer, M. W., and S. B. Lundstedt. "Understanding Tax Evasion." Public Finance, 31 (1976), 295-304.

Svensson, J. "Who Must Pay Bribes and How Much? Evidence from a Cross Section of Firms." Quarterly Journal of Economics, 118 (2003), 207-230.

Svensson, J. "Eight Questions about Corruption." Journal of Economic Perspectives, 19 (2005), 19-42.

Torgler, B. Tax Compliance and Tax Morale: A Theoretical and Empirical Analysis. Cheltenham, UK: Edward Elgar (2007).

Wooldridge, J. M. Econometric Analysis of Cross Section and Panel Data. Cambridge, MA: MIT Press (2002). 